\title{
Investigating the Effect of Different Methods of Financial Supply on the Profitability Ratios of Companies Accepted in Tehran Stock Exchange
}

\author{
Hamed Ghafouri
}

\author{
Corresponding author, Master of in MBA- Financial Trends
}

\section{Doi:10.5901/mjss.2015.v6n1p339}

\begin{abstract}
One of the most important stimulating factors that have an accelerating role in achievement the countries to stage of development are capital adequacy and financial supply. To supply required capital, there are different ways. These ways mainly consist of the use of debt, the use of shareholders' capital in the form of common stock, the use of retained earnings, the combination of these methods and etc. Different ways of financial supply have various risks and efficiencies and different economic, accounting, functional, liquidity and profitability variables of the company are markedly changed under the influence of different methods of financial supply. In this study, the influence of different conventional methods of financial supply (retained earnings, common stock and debt) as independent variables on profitability of companies (return on asset, operating profit margin, net profit margin and return on equity) as dependent variables has been examined. The present study is applicable and descriptive in correlation branches from view points of objective and the nature of method, respectively. Simple random and cluster methods were used for sampling. Thus, at first, the samples were selected among various industries active in Tehran Securities and Exchange using simple random sampling. And then all of the companies in the oil and petrochemical industry during years 2005-2012 were considered as research sample. Test results of the assumptions show that there was a statistically significant relationship between financial supply through retained earnings and the logarithm of return on equity and but a statistically significant relationship was not found between the financial supply of common stock and debt. Also, results showed that a statistically significant relationship exists between financial supply through retained earnings and debt with net profit margin. But a statistically significant relationship was not observed between financial supply through debt, retained earnings and common stock with return on asset and between financial supply through debt, retained earnings and common stock with operational profit margin.
\end{abstract}

Keywords: Common stock, Debt, Return on equity, Operational profit, net profit of profitability

\section{Introduction}

The concept of financial supply determines the composition of essential resources for investment (Damodaran, 2010:616). Financial supply methods are very effective for continuing the activity and implementation of profitability projects in growth process of companies and they result in continuing the life of companies in today competitive world. Financial supply is conducted using various short- and long-term methods and companies can supply their required financial sources from inside (for example, retained earnings) or outside of company (through issuance of stock or bonds). The main aim of companies is increasing the return on equity and therefore they use a method that helps them to achieve this goal. Enhancement of return on equity and consequently decrease of capital costs increase value of the company. Indeed, investors such as shareholders or suppliers of loans and log-term facilities have accepted the risk of not receipting it by giving their own capital or money to the company and want a return equal with capital cost of the company (Mashayekhi and Shahrokhi, 2009, p. 13). Determining the optimal structure of capital is one of the essential issues of financial supply of companies. This point has an important application in the field of making a decision about financial supply of current operation and investment plans of companies. Due to lower risk of debt securities, expected return of creditors is also lower than that of the shareholders. Therefore, the more use of debt for more financial supply, the lower total capital cost and the more profitability for the company; and it is true up to a given level. In spite of this, financial risk of the company increases with enhancement of debt and consequently creditors want higher interest rate. In this situation, the total capital cost increases. Consequently, optimal structure of capital must exist between two limits of financial supply (stock and debt) (Kordestani and Najafi, 2008: 14). Some of theorists have stated that much more money can be earned using wise decisions made in the field of investment but the fact is that it must be hesitated and the role of correct financial supply must be considered. Undoubtedly, this theory not only does not deny the important role of financial supply but also prioritize the investment. Therefore, if decisions related to financial supply were made consistent 
with company investment strategy not against it, it can result in more profitability. Topics of the theory are in relation to capital structure following on achieving a limit of balance between two main resources of financial supply, namely debt and return on equity to can maximize the stock value of the company at that point and minimize the cost of supply of financial resources. Capital structure decisions in real world are usually made according to many factors and based on different conditions and they are often based on judgment and viewpoints of managers. Financial theories also help identifying effective factors on value of company and rationalizing decisions in determining capital structures. Overall, financial supply resources in view point of a company consist of debt and return on equity. Applying each of these resources in capital structure of the company has a specific property and it is done in accordance with dominated conditions. Debts due to their high priority for paying back and being known the price, usance, and interest rate has a lower risk than capital in view point of creditors. Accepting higher risk, investors also expect more returns; based on this, it is expected whatever the institution use more borrowing, the capital cost decreases, however, enhancement of debt and bankruptcy risk result in increasing the expectations of investors and it is possible to offset the cost of savings. Various theories have been stated that some of them did not considered any difference among financial supply sources and some have gone so far as that they propose that a company can maximize its own value using $100 \%$ debt. Enhancement of shareholders' wealth is final goal of profit institutions. Use of correct methods of financial supply and the type of financial supply methods selected in companies for implementation of profitable projects can play a fundamental role in increasing the company value and shareholders' wealth. Because if a company attracts proper sources and has optimal consumptions, the profitability and value of the company increase. On the other hand, some of researchers of financial science know the profitability of the company resulted from management performance not from its capital structure. In their opinion, the value of the company and shareholders' wealth can be affected by performance of managers. In this research we aim to answer this question that whether various methods of financial supply are effective on profitability ratios of companies? Indeed, the main matter in this research is answering to this question: how is the effect of various common methods of financial supply (retained earnings, common stock, and debt) on profitability of companies (return on assets, profit margin, and return on equity)? Final purpose of various researches in the field of capital structure and different methods of financial supply is to achieve the optimal capital structure in any institution and organization according to task nature and activity of that organization. What meantime and before design of optimal model of capital structure that has high importance is to discover the relationship between the profitability of organization and various methods of financial supply. Indeed, investigating the relationship between various methods of financial supply and the profitability is a prerequisite to achieve the optimal capital structure in any organization. This study aims to determine the relationship between various methods of financial supply and the profitability of companies by understanding the necessity and importance of this matter.

\section{Hypotheses of Research}

1) There is a significant relationship between return on equity and various methods of financial supply.

2) There is a significant relationship between return on assets and various methods of financial supply.

3) There is a significant relationship between operational profit margin and various methods of financial supply.

4) There is a significant relationship between net profit margin and various methods of financial supply.

\section{Research Method}

The present research from view points of purpose and information collection method is applicable and descriptive of a kind of correlation with branch of regression analysis, respectively. Correlation study is used when a researcher has two or several groups of different information related to one group from two or several groups and the purpose is to study changes of two or several factors resulted from changes of the other one or several factors. Regression analysis is one of various kinds of correlation study that it will be used in this study. This study can be called "applicable" because by considering the importance of profitability for company managers and beneficiaries, determining the relationship between financial supply and profitability helps investors to predict future profitability and then to determine the value of the company and also helps company management to make a decision about determining the correct method of financial supply. Also, this study is a library study from view point of data collection because with referring to balance sheet, documents, notes and financial statements of bourse companies, information related to variables of study are collected. In order to collect data and required information for study, library studies in branch of documentation and information existed in texts related to the topic, various internet websites such as irbourse.com, tsemc.com, and www.rdis.ir and software applications that present information in the field of bourse companies like Rahavard Novin were used. Statistical 
population of study consists of all companies accepted in Tehran Securities and Exchange. Cluster and simple random methods were used for sampling. Thus, at first, the samples were selected among various active industries in Tehran Securities and Exchange using simple random sampling. And then all of the active companies in the oil and petrochemical industry during years 2005-2012 were considered as research sample. In order to analyze information, Pearson's correlation coefficient test was applied.

\section{Conceptual Model of Study}

Study model consists of three independent variables that are separately fitted to three dependent variables. Graphical chart of study model is shown as follows:

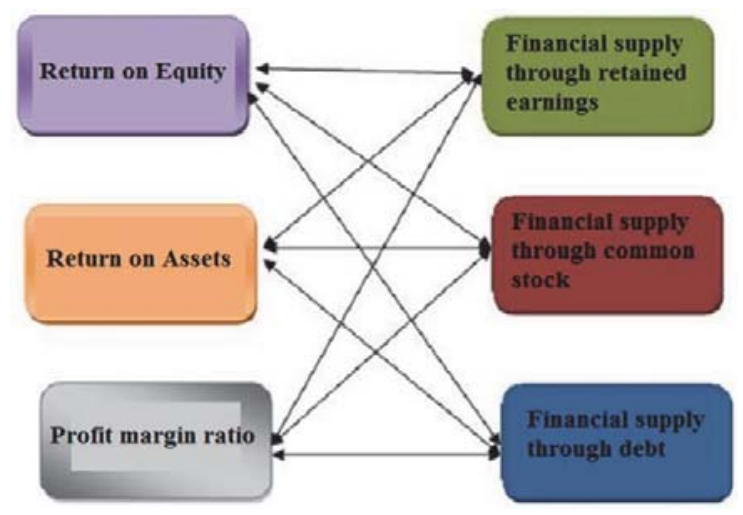

Figure 1 - Conceptual model of study

Independent variables in this study are financial supply methods that three prominent methods including through retained earnings, through issuance of common stock, and through debt for financial supply have been considered according to statistical sample and way of financial supply of these companies that financial supply through debt and issuance of common stock are regarded as external sources of financial supply and they have a high importance from view point of their effects on financial risk and control of companies. Financial supply through retained earnings also is known as the most important and the most common internal method of financial supply. Thus, these three methods have been selected as independent variables of study. These variables are theoretically and operationally described below:

a) Financial supply through retained earnings

$E=\left(C_{1}-C_{0}\right)-A$

In above equation, $E, C_{0}, C_{1}$, and $A$ represent financial supply through retained earnings, capital before capital increase, capital after capital increase, and capital increase percentage from reserves and present receivables, respectively.

b) Financial supply through issuance of common stock

$S=\left(C_{1}-C_{0}\right)-B$

In above equation, $\mathrm{S}, \mathrm{C}_{0}, \mathrm{C}_{1}$, and $\mathrm{B}$ represent financial supply through issuance of common stock, capital before capital increase, capital after capital increase, and capital increase percentage from shareholders' cash provided, respectively.

c) Financial supply through debt

$D_{t}=d_{t}-d_{t-1}$

In above equation, $D_{t}, d_{t}$, and $d_{t-1}$ represent financial supply through debt duration $t$, supply through debt duration $t$, and financial supply through debt duration $\mathrm{t}-1$, respectively.

\section{Dependent Variables of Research}

a) Return on equity

It is obtained from division of net profit belongs to common shareholders of company (i.e. net profit minus paid dividend to owners of preferred stock) by common equity. It is one of the profitability ratios. Profitability ratios show the success of company in obtaining net return on sales with investment. The purpose of management is to maximize the 
return for shareholders. Thus, return on equity is the most important criterion for measuring the company success to achieve mentioned purpose (Taghavi, 2006).

$$
\begin{aligned}
& \mathbf{R O E}= \frac{\text { Net profit }}{\text { Equity }} \\
& \text { b) Return on assets } \\
& \text { ROA }=\frac{\text { Net profit }}{\text { Total assets }} \\
& \text { c) Profit margin ratio }
\end{aligned}
$$

Profit margin ration $=\frac{\text { Net profit }}{\text { Sales }}$

\section{Research Background}

Pecking order theory of finance was firstly introduced by Myers (1984) as below:

1- Companies prefer domestic financial supply sources (retained earnings).

2- A division ratio of targeted profit was selected according to investment situations and sudden changes in divided profit were avoided.

3- Making a constant profit division policy with unexpected changes in profitability and investment situation means internally generated cash flows are sometimes greater and sometime lower than capital costs. If cash flows are greater than capital costs, the company pays its own debts back. If cash flows are lower than capital costs the company uses its own balance of accounts or tries to sell its own marketable securities (short-term).

4- If you need external financial supply sources; companies first release the safest securities. Thus, companies first use debt, then if possible, convertible bonds or common stock for financial supply (Brealey and Myers, 2000).

Meyer (1989) compared and investigated financial structures of companies in eight different industrial countries over the period 1970-85. Some of his results are as follows:

1- Retained earnings is the most important financial supply sources of all countries, especially in England, Canada and America, so that more than $75 \%$ of investments in America and England have been provided through retained earnings.

2- An inverse relationship exists between the use of retained earnings and bank credits.

3- Small and medium companies more than large companies use external sources and they in financial supply have more connection with commercial banks and use lower securities for financial supply (Myer, 1989).

- Singh and Hamid (1992) investigated financial supply methods of fifty developed countries and developing countries. The main results of this study are as follows:

1- Companies located in developing countries mostly use from foreign sources for financial supply.

2- Companies located in developing countries create new stocks to increase their net assets.

In a study, Courbet and Jenkinson investigated financial supply methods in developed countries over the period from 1970 to 1989. The main results of this study are as follows:

1- The most important financial supply method in companies of all the countries studied is internal resources.

2- Small amounts of financial supply sources in the investigated countries are bonds and securities.

3- The most important external source of financial supply is bank mortgages to companies under study. Pahor and Mramor (1990) in their research found that a non-linear relationship between financial ratios and internal rate of return exists in certain industries.

- Fama and French (1995) in a study about financial supply decisions emphasized the preferred model. In this study, they obtained considerable and questionable results about this model.

They concluded from their investigation that it looks financial decisions reverse the main predictions of the preferred model about that how often firms and under what circumstances issue securities.

They consider negative relationship between leverage and profitability documented in many previous works (e.g., Tytmen and Wessells, Fama and French) as a serious contradiction for the main predictions of the model about tax and interests of representation of debt. Thus, they see both the parallel and preferred models to have serious.

- Casser (2005) investigated the relationship between the amount and type of financial supply and future and past profitability of the companies from the New York Stock Exchange.

The results of investigation showed that changes in company profitability have orderly a relationship with amount 
and kind of financial supply.

Jang and Park (2011) investigated the relationship between growth and profit in companies that have revised their financial statements. They used generalized dynamic moment panel. The results of this study showed that the predicted profit has a positive effect on the current growth, but previous growth has a reverse relationship with current profit. Pourheidari and Ghaffarlou (2012) showed that companies that finance through long-term debts, unexpectedly, do not decrease conditional conservative level not only during financial supply but also earlier period. But companies that finance through equity, expectedly, decrease conditional conservative level in financial reports both during financial supply and earlier period; because this results in improving the expectations of investors and shareholders from future company performance and it accompanies by more efficient financial supply.

- Namazi and Parisaei (2003) investigated the effect of capital structure of companies in Tehran Stock Exchange on the return and risk. They divided companies into two samples including companies that have used credits to supply their needed funds and companies that have issued stocks to supply their required funds. Then, they calculated the stock returns of first and second sample companies during years from 1996 to 2001 and obtained total average of return of each statistical sample. They using t-test with $95 \%$ level of confidence concluded that financial supply method has not had a significant effect on the stock return of companies under study.

- Jaber Zahmatkesh (2004) in his study aims to investigate the effect of capital structure on the profitability of active companies in cement industries accepted in Bourse during years from 1998 to 2002. The results show that there is not a significant relationship among debt ratios, coverage of interest costs, debt to equity, and stock return in a $95 \%$ level of confidence. Also, there is not a significant relationship among financial supply methods, financial structure of active companies in cement industry, and their stock return and stock return is not affected by debt amount in financial structure of companies.

- HassanAli Sinaee (2007) in a paper studied the effect of various factors on the use of leveraged financial supply method. Obtained results not only emphasize the effect of specific factors of every industry on the financial structure of companies, but also they have presented especial suggestions for managers of companies.

- Hassan Ghalibaf and Salma Izadi (2009) in a paper have investigated the relationship of factors such as amount, profitability, collateral assets, commercial risk and liquidity with use of debt in capital structure of companies in order to test a new theory about capital structure like static trade off theory in Iranian companies. The results showed that during study the factors of amount, profitability and liquidity have a reverse significant relationship with capital structure of companies accepted in Tehran Stock Exchange. In summary, results obtained from this study do not confirm static trade off theory in Tehran Stock Exchange.

- Mojtahedzadeh, Alavi Tabari and Khodabakhshi (2009) studied the relationship of financial supply and operational performance in companies accepted in Tehran Stock Exchange. Their results showed that financial supply not only does not an effect on before and after operational performance but also type and volume of financial supply do not have an effect on most measures of operational performance.

\section{Findings}

Kolmogorov-Smirnov test was used to investigate the normality or non-normality of distribution of variables. If calculated significance level in Smirnov test that was calculated with statistics $Z$ is higher than 0.05 in error level of 0.05 , the mentioned variable is normal and if it is lower than 005 , the variable is not normal. Output table of SPSS software is given bellow:

Table 1 - Normality test using Kolmogorov-Smirnov test

\begin{tabular}{|c|c|c|c|c|c|c|}
\hline & $\begin{array}{c}\text { Operational } \\
\text { profit }\end{array}$ & $\begin{array}{c}\text { Net } \\
\text { profit }\end{array}$ & $\begin{array}{c}\text { Return on } \\
\text { asset }\end{array}$ & $\begin{array}{c}\text { Return on } \\
\text { equity }\end{array}$ & $\begin{array}{c}\text { Logarithm of net } \\
\text { profit }\end{array}$ & $\begin{array}{c}\text { Logarithm of return on } \\
\text { equity }\end{array}$ \\
\hline Kolmogorov-Smirnov Z & 0.832 & 1.99 & 0.991 & 3.522 & 0.432 & 1.057 \\
\hline Sig & 0.493 & 0.001 & 0.280 & 0.000 & 0.992 & 0.214 \\
\hline
\end{tabular}

It is observed that the significance level (Sig) of return on asset and operational profit is higher than 0.05 thus, normality of data is confirmed. But significance level (Sig) of net profit and return on equity is lower than 0.05 thus normality of data is rejected and we must use logarithmic transformations to normalize variables. Also, normality of logarithm of net profit 
and logarithm of return on equity were tested and results showed that the significance level (Sig) of net profit and logarithm of return on equity is higher than 0.05 and the normality of data is confirmed.

First hypothesis: there is a significant relationship between logarithm of return on equity and variuos methods of financial supply.

Table 2 - Results of Pearson's correlation coefficient for first hypothesis.

\begin{tabular}{|c|c|c|c|c|}
\hline & & Debt & Retained earnings & Common stock \\
\hline Logarithm of return on equity & Pearson correlation & .022 & .374 & .020 \\
\hline & Sig. (2-tailed) & .902 & .032 & .902 \\
\hline
\end{tabular}

According to above table, since the significance level (Sig) of two methods of debt and retained earnings is higher than $5 \%$, the hypothesis of zero that means insignificance of correlation is not rejected. Therefore, with $95 \%$ confidence we can say that there is not a significant relationship between logarithm of return on equity (ROE) with debt methods and common stock, but a significant relationship with retained earnings is observed ( $p=0.032, r=0.374)$.

Second hypothesis: there is a significant relationship between return on asset and various methods of financial supply.

Table 3 - Results of Pearson's correlation coefficient for second hypothesis

\begin{tabular}{|c|c|c|c|c|}
\hline & & Debt & Retained earnings & Common stock \\
\hline Return on asset & Pearson correlation & .066 & .274 & -.600 \\
\hline & Sig. (2-tailed) & .694 & .096 & $\mathrm{P}<001$ \\
\hline
\end{tabular}

According to above table, inasmuch as the significance level (Sig) of debt and retained earnings is higher than error level $(5 \%)$, the hypothesis of zero that means insignificance of correlation is not rejected. But, the significance level of debt is zero and lower than $5 \%$. Therefore, with $95 \%$ confidence we can say that there is a reverse significant relationship between return on assets (ROA) and common stock ( $<<0.001, r=-0.600)$.

Third hypothesis: there is a significant relationship between operational profit margin ratio and various methods for financial supply.

Table 4 - Results of Pearson's correlation coefficient for third hypothesis

\begin{tabular}{|c|c|c|c|c|}
\hline & & Debt & Retained earnings & Common stock \\
\hline Operational profit margin ratio & Pearson correlation & .160 & .323 & -.491 \\
\hline & Sig. (2-tailed) & .338 & .048 & $\mathrm{P}<001$ \\
\hline
\end{tabular}

According to above table, inasmuch as the significance level (Sig) of debt method is higher than error level (5\%), the hypothesis of zero that means insignificance of correlation is not rejected. But, the significance level of common stock and retained earnings is lower than 0.05 . Therefore, with $95 \%$ confidence we can say that there is a negative significant relationship between operational profit margin ratio and common stock $(p<0.001, r=-0.491)$. And there is a positive significant relationship between operational profit margin ratio and retained earnings $(p=0.048, r=0.323)$.

Fourth hypothesis: there is a significant relationship between logarithm of net profit margin ratio and various methods of financial supply.

Table 5 - Results of Pearson's correlation coefficient for fourth hypothesis

\begin{tabular}{|l|c|c|c|c|}
\hline & & Debt & Retained earnings & Common stock \\
\hline Logarithm of net profit margin ratio & Pearson correlation & .606 & .713 & -.492 \\
\hline & Sig. (2-tailed) & .000 & .000 & .006 \\
\hline
\end{tabular}

According to above table, inasmuch as the significance level (Sig) of each of financial supply methods is lower than error level (5\%), the hypothesis of zero that means insignificance of correlation is rejected. Therefore, with $95 \%$ confidence we can say that there is a significant relationship between net profit margin ratio and each of financial supply methods. This 
relationship is in a reverse direction with common stock $(p=0.006, r=-0.492)$ and in a direct direction with retained earnings $(p<0.001, r=0.713)$ and debt $(p<0.001, r=0.606)$.

\section{Discussion and Conclusion}

We in this study aim to investigate the relationship of various methods of financial supply and profitability. Different methods of financial supply used in this study including retained earnings, issuance of common stock and debt for valid ratios of profitability of return on equity, return on assets and profit margin (net and operational) were tested. Results of this study showed that there is not a significant relationship between logarithm of return on equity (ROE) with debt methods and common stock but there is a positive significant relationship between return on equity (ROE) and retained equity.

In second hypothesis, the relationship between return on equity (ROE) and various methods of financial supply was investigated and the results showed that a reverse significant relationship exists between return on asset (ROA) and common stock. In third hypothesis, the relationships between operational profit margin and various methods of financial supply were examined and the results showed that a negative significant relationship exists between operational profit margin and common stock and a positive significant relationship exists between operational profit margin and retained earnings. In fourth hypothesis, the relationships between net profit margin and various methods of financial supply were investigated. The results showed that a significant relationship exists between net profit margin and each of financial supply methods. This relationship is a reverse direction with common stock and in a direct direction with retained earnings and debt. In relation to lack of a significant relationship between financial supply methods including retained earnings and issuance of stock with various profitability variables such as ROA and operational profit margin, we can say that due to being newly establishment, newly accepted companies in Bourse of the country have not had high tendency to save the profit. Newly companies accepted in Bourse through distribution of better profit at first years of acceptance have tended to announce their shareholders this point that the company was working on profitability and distribution of high profits among shareholders. In capital markets with semi-strong efficiency, lack of distribution of good profit always does not mean the unsuccessfulness and participants in market have been aware of accumulating profit due to existence of proper investment opportunities in future. The results obtained from the study are consistent with the results of Myers and Fernandez (1998), Shiam, Sander and Myers (2001), Drabtez and Fix (2003), Chen and Hams (2004), Casser (2005), Delavari (2007), Ahmadi (2006), and Zahmatkesh (2004). Also, prevailing theories and studies conducted in Bourse of the other countries show that activities of external financial supply sources and investment, each of them separately has a negative effect on stock return (Khani, 2012). Capital management and supply method of financial sources for utilization have been considered and in a study conducted in Finland, results showed that productivity of companies involves in management of optimal capital (Enqvist et al., 2014). Results of a study conducted by Karimzadeh and colleagues (2013) also showed that financial supply source has a significant effect on the reaction of market to reported profits, so that with enhancement of reliance of the company on financial supply through debt the reaction of market to reported profits decreases. Also, results showed that the shareholders' focus on the reaction of the market has a significant effect on the reported profits, so that with enhancement of shareholders' focus, the reaction of market to the reported profits by companies increases. Considering the positive relationship between variables of return on assets and financial supply through debt and existence of a severe negative relationship between this method of financial supply and profit margin (operational and net), it is suggested to the managers of the companies to pay attention to company situation, status of market, shareholders, and the other parameters if use of this method of financial supply is necessary and make a decision according to the current conditions of the company. It is propose to investors to pay attention to debt ratio at the time of buying and assessing the bonds and considering its high amount up to a proper limit as strength for the company. It is proposed to analyzers to pay attention to return ratios instead of profit margin ratios at the time of assessing companies and comparing leveraged and non-leveraged companies. Because low ratios of profit margin in leveraged companies may not be correctly interpreted. In determining the relationship among variables, it is found that financial supply of companies through debt increases return on asset, however, profit margin (net and operational) also decreases with enhancement of company debt. Thus, it is proposed to company management to consider various aspects in order to financial supply and select a proper method and do not suffice for easy availability of one of methods and using it promptly. In determining the relationship among variables in this study, it is found that existence or lack of a significant relationship and even directness or reversion of the relationship between various methods of financial supply and profitability depends on definition of profitability by a company. When return on assets is used as an index of profitability for a company, it is concluded that debt has a direct significant relationship with the profitability of a company; when profit margin is used as an index of profitability for a company, it is concluded that debt has a negative significant 
relationship with the profitability of a company; when return on equity is applied as an index of profitability for a company, it is concluded that debt does not have any significant relationship with the profitability of a company. Thus, it is considered that definition of profitability by a company has a supplier role in making a decision in the field of selecting a proper financial supply method according to effect of various methods on company profitability. Therefore, it is proposed to develop a same, uniform, and comprehensive definition for profitability in Bourse and a specific and standard accounting method to be used for measurement and calculation of profitability. Large companies with high capital can use retained earnings and issuance of new stock for financial supply of their own required liquidity.

\section{References}

Pourheidari, O., Ghaffarlou, A., (2012), financial supply and changes of conditional conservative level of accounting, scientific-research quarterly Journal of accounting and audit, 18(66), pp. 15-28.

Taghavi, M., (2006), financial management, Tehran: Payam-e-Nour University Press, first volume.

Khani, A., Afshari, H., (2012), abnormality of financial supply and investment in Tehran Stock Exchange between years 2004-2010, scientific-research publication of financial research, 14(2), pp. 31-46.

Zahmatkesh, J., (2005), assessment of nature of capital structure and its effect on stock return of active companies in cement industry during years 1998-2002, M.Sc. thesis, Islamic Azad University, science and research branch.

Sinaee, H.A., (2009), investigation the effective factors on use of financial beverage in public joint stock companies, quarterly journal of accounting studies, No. 4, faculty of accounting and management, Allameh Tabatabaee University.

Ghalibaf Asl, S. H., Izadi, S., (2009), empirical study of static trade off theory in Tehran Stock Exchange, The Journal of knowledge and development, No. 26, faculty of administrative and economic science, Mashhad.

Kordestani, G., Najafi, Omran M. (2008), a review on capital structure theories, accountant journal, 23 ${ }^{\text {th }}$ year, No. 198, Tehran.

Karimzadeh Mostafa, Norouzi, Mohammad, Nadem, Masoud, (2013), investigating the effect of financial supply sources and shareholders' focus on the reaction of the market to the reported profits, monetary economics, $20^{\text {th }}$ year, No. 5 .

Mojtahedzadeh, Vida, Alavi, Seyed Hossein, Khodabakhshi, Najmeh, (2009), the relationship and operational efficiency in companies accepted in Tehran Stock Exchange, accounting studies, No. 1, Tehran.

Mashayekh, Shahnaz, Shahrokhi, Samaneh, (2006), effective factors on capital structure, accountant journal, 21 th year, No. 176, Tehran.

Namazi, Mohammad, Heshmati, Morteza, (2007), investigating the effect of structures and delay variables on capital structure of companies accepted in Bourse, Journal of accounting and audit, No. 49, faculty of management, University of Tehran.

Namazi, Mohammad, Shirzadeh, Jamal, (2005), investigating the relationship of capital structure with the profitability of companies accepted in Tehran Stock Exchange (emphasizing on type of industry), Journal of accounting and audit, No. 42, faculty of management, University of Tehran.

Brealey, R. \& S. Myers. (2000), Principles of Corporate Finance. Sixth Edition, McGraw Hill.

Casser, Gavin John, (2005), External financing and firm operating performance, working paper, University of California, Berkeley.

Corbett, J. \& T. Jenkinson. (1994), the Financing of Industry, 1970-89: A Comparison. CERR Discussion Paper, 948.

Damodaran, A. (2010), Applied Corporate Finance. (3rd edition), John Wiley.

Enqvist, J., Grahamb, M., Nikkinen J., (2014). The impact of working capital management on firm profitability in different business cycles: Evidence from Finland. Research in International Business and Finance Volume 32, August 2014, Pages 36-49.

Fama Eugene and Kenneth French (2002), "Testing Trade-off and pecking order predictions about dividend and debt", Review of Financial studies 15, pp 1-33.

Fama, Eugene F., and Kenneth R. French, (1995), Size and book-to-market factors in earnings and returns, Journal of Finance 50, 131155.

Fama, Eugene F., and Kenneth R. French, (1992): The Cross-Section of Expected Stock Returns, Journal of Finance, 47, pp. 427-465.

Jang, S.S. \& Park, K. (2011), Inter-relationship between firm growth and profitability. International Journal of Hospitality Management, 30(4): 1027- 1035.

Mayer, C. (1990), Financial Systems, Corporate and Economic Development in Asymmetric Information, Corporate Finance and Investment, R.GInHubbard Edition, The University of Chicago press.

Pahor, M. \& C. Mramor, D. (2001), Testing Nonlinear Relationships between Excess Rate of Return on Equity and Financial Ratios. University of Ljubljana. Papers.ssrn.com.

Singh, A. \& J. Hamid. (1992), Corporate Financial Structure in Developing Countries. IFC Technical Paper 1. Washington D.C. 